\title{
Article \\ Potato Farming Systems from a Social-Ecological Perspective: Identifying Key Points to Increase Resilience in a High Andean Productive Landscape
}

\author{
Eliana Martinez ${ }^{1, * \mathbb{D}}$, Lizeth Tatiana Luna-Mancilla ${ }^{1}\left(\mathbb{D}\right.$, Housseman Steven Ramos-Zambrano ${ }^{1}$ (D) \\ and Ulianova Vidal-Gomez ${ }^{2}$ (D) \\ 1 Corporación Colombiana de Investigación Agropecuaria AGROSAVIA, Pasto 520038, Colombia; \\ lluna@agrosavia.co (L.T.L.-M.); hramos@agrosavia.co (H.S.R.-Z.) \\ 2 Integrated Pest Management Group, Agronomy College, Campus Bogotá, National University of Colombia, \\ Bogotá 111331, Colombia; uvidalgo@gmail.com \\ * Correspondence: emartinezp@agrosavia.co
}

check for updates

Citation: Martinez, E.;

Luna-Mancilla, L.T.;

Ramos-Zambrano, H.S.;

Vidal-Gomez, U. Potato Farming

Systems from a Social-Ecological

Perspective: Identifying Key Points

to Increase Resilience in a High

Andean Productive Landscape.

Sustainability 2022, 14, 2491.

https://doi.org/10.3390/

su14052491

Academic Editor: Anastasios

Michailidis

Received: 21 December 2021

Accepted: 15 February 2022

Published: 22 February 2022

Publisher's Note: MDPI stays neutral with regard to jurisdictional claims in published maps and institutional affiliations.

Copyright: () 2022 by the authors. Licensee MDPI, Basel, Switzerland. This article is an open access article distributed under the terms and conditions of the Creative Commons Attribution (CC BY) license (https:/ / creativecommons.org/licenses/by/ $4.0 /)$.

\begin{abstract}
Social-ecological resilience (SER), understood as the capacity to prevent, react to, and mitigate crises that affect social-ecological systems, provides an integrative framework to analyze agricultural challenges. Based on this approach, key points that affect the sustainability of productive landscapes are addressed and evaluated, providing a baseline from which to improve farming systems at different scales. Hence, the aim of this work is to assess SER in potato crops in the Nariño area in southwestern Colombia, a region where strategies to increase resilience must be implemented. Following the methodology proposed by the UNU-IAS (2014), potato producers' thoughts and perceptions were evaluated by implementing eleven workshops in seven municipalities. Five main integrative factors (twenty indicators of resilience) were examined and scored during the assessment: (1) governance and social equity, (2) livelihood and well-being, (3) knowledge and innovation, (4) landscape diversity and ecosystem protection, and (5) agrobiodiversity and sustainable natural resource management. Participants evaluated each indicator from 1 to 5 (1 being low performance and 5 extremely good performance). The results were calculated and averaged. Prior to the assessment, participatory techniques to generate collective reflection on resilience and landscape management were performed. The results showed that farmers rated SER resilience from low to moderate (from 2.5 to 3.2), with "well-being" (2.5) and "knowledge and innovation" (2.7) being the worst-rated factors. The data evidence deficiencies in all the indicators examined. Issues that constrain SER are related to the lack of capacity to create bio-industries, small livelihood portfolios, pollution, loss of natural areas (which impacts biodiversity and ecosystem services), and the loss of ancestral knowledge. The producers requested, as short-term actions, increases in technical assistance (to promote innovation and business initiatives) and farm diversification programs (to take advantage of their native potatoes diversity). They also agreed on the need for associative figures to enhance capacity-building among producers. These findings confirm deficiencies that minimize the sustainability of this system. Actions that impact positively almost all indicators are required to improve not only productivity but also the population's well-being.
\end{abstract}

Keywords: social-ecological resilience (SER); sustainability; potato crops; agrobiodiversity; Colombia

\section{Introduction}

The potato farming system is the main livelihood strategy for most of the families that inhabit Nariño, a strategic region in the southern Andes of Colombia. Potato production here is ranked as third in the country (21\% of the planted area, 777.645 tons/year) [1] and represents approximately $5 \%$ of the area's gross domestic product [2]. This crop contributes employment to ca. 25,000 households (all family members play a strategic role), providing considerable amounts of manual labor (ca. 3,600,000 wages) and indirect jobs (ca. 350,000) 
to this population [1]. Despite its significance, this is still a traditional farming system where $80 \%$ of the growers use small-scale plots (ca. $5000-30,000 \mathrm{~m}^{2}$ ) for production. Most plots are also located on hillsides, which negatively affects productivity and sustainability [1].

The potato crops settled in high mountain environments encompass two main ecosystems: high Andean forests and páramos. Both habitats have been considered strategic for water supply/regulation. They also have a unique biological species richness that requires protection [3]. Thus, many challenges arise from growing potato in these zones, such as (1) the decline of soil water retention and structure that affects organic matter and nutrient availability, especially in steep and rugged slopes [4]; (2) the loss of nitrogen and phosphorous caused by increased water runoff that ends up polluting streams and rivers [5,6]; and (3) habitat fragmentation of natural areas due to agricultural intensification resulting in biodiversity loss [5]. This system is also highly vulnerable to unfavorable weather events because of cultural practices like planting furrows downhill, which accelerates soil erosion [1].

This production system is susceptible not only to adverse environmental events but also those triggered by unexpected socio-economic threats. Price volatility, reduced profitability, trade intermediary loads, and high input costs all discourage farmers from continuing investing in potato. This situation is intensified by production seasonality, tuber embrittlement, price/demand inelasticity, and lack of storage facilities [7]. Recently, potato profits have not exceeded production costs, making the financial uncertainty for growers in this market direr [8].

Unfortunately, current technology and productivity based approaches are insufficient to overcome these mounting challenges in this agricultural production system $[9,10]$. Contemporary work dealing with strategies to improve the living standards of a population instead has focused on incorporating adaptive management [11-13], meaning that stakeholders should assess, design, and implement activities based on what they have learned to thus manage their landscapes in a way that allows them to face uncertainty [14,15]. The aim of this should be holistic by not simply implementing strategies that react to or alleviate the effects of detrimental environmental events but buffer social, ecological, and agricultural threats as well $[16,17]$. This is, in other words, social-ecological resilience (SER) or the capacity of a social-ecological system to absorb disturbance, adapt, and reorganize while undergoing change to still retain essentially the same functionality and structure [18-23].

Three factors that define SER as a concept and provide an integrating framework to analyze productive systems are (1) absorption, the capacity to absorb disturbance; (2) adaptability, the capacity of stakeholders to influence their own processes; and (3) transformability, the capacity of creating alternative systems to avoid losses [21,24-26]. Ambiguity still exists about how to practically address these attributes to operationally analyze and evaluate SER $[13,21,22,27]$, but conceptual frameworks and methodological strategies are emerging $[23,25,28]$, combining quantitative and qualitative methods at different scales of analysis to address these questions.

In Latin America, attempts for assessing SER have focused on (1) conservation and protected areas [29]; (2) comparing traditional vs. ecological agricultural strategies [30-32]; and (3) evaluating agricultural and ecological regions [33-37]. More research is still needed since these studies have shown that there is no SER, and there are no strategies or mechanisms that may promote community thinking at a landscape scale [38].

In this study, we assess SER in a high-mountain potato-farming system by implementing the methodology proposed by UNU-IAS, Biodiversity International, IGES, and UNDP [28]. To this end, participants qualitatively evaluated twenty SER-related indicators arranged in five main factors: (1) governance and social equity, (2) livelihood and well-being, (3) knowledge and innovation, (4) landscape diversity and ecosystem protection, and (5) agrobiodiversity and natural resource management. We hypothesized that: (1) identifying the social-ecological drivers that undermine resilience in this region is the first step for producers to start implementing strategies to strengthen their capability of absorbing, adapting, and positively transforming their environment; (2) the assessment 
process catalyzes collective analysis and constructive criticism, which facilitate collaborative initiatives that transcend household and farm boundaries (a pivotal SER concept); (3) involving producers in the assessment increases communication and collaboration across stakeholders, which may turn into major programs and policies that promote a long-term sustainable potato production. The ultimate objective of this work was to gather information from which to design and implement strategies to improve the living conditions of this population and increase resilience in this productive landscape.

\section{Materials and Methods}

\subsection{Study Site}

The SER assessment was carried out in Nariño, Colombia. Seven municipalities (Cuaspud, Aldana, Ospina, Guaitarilla, Tangua, Pasto-Socorro, and Yacuanquer) were selected as study areas based on their production attributes and accessibility (Figure 1).

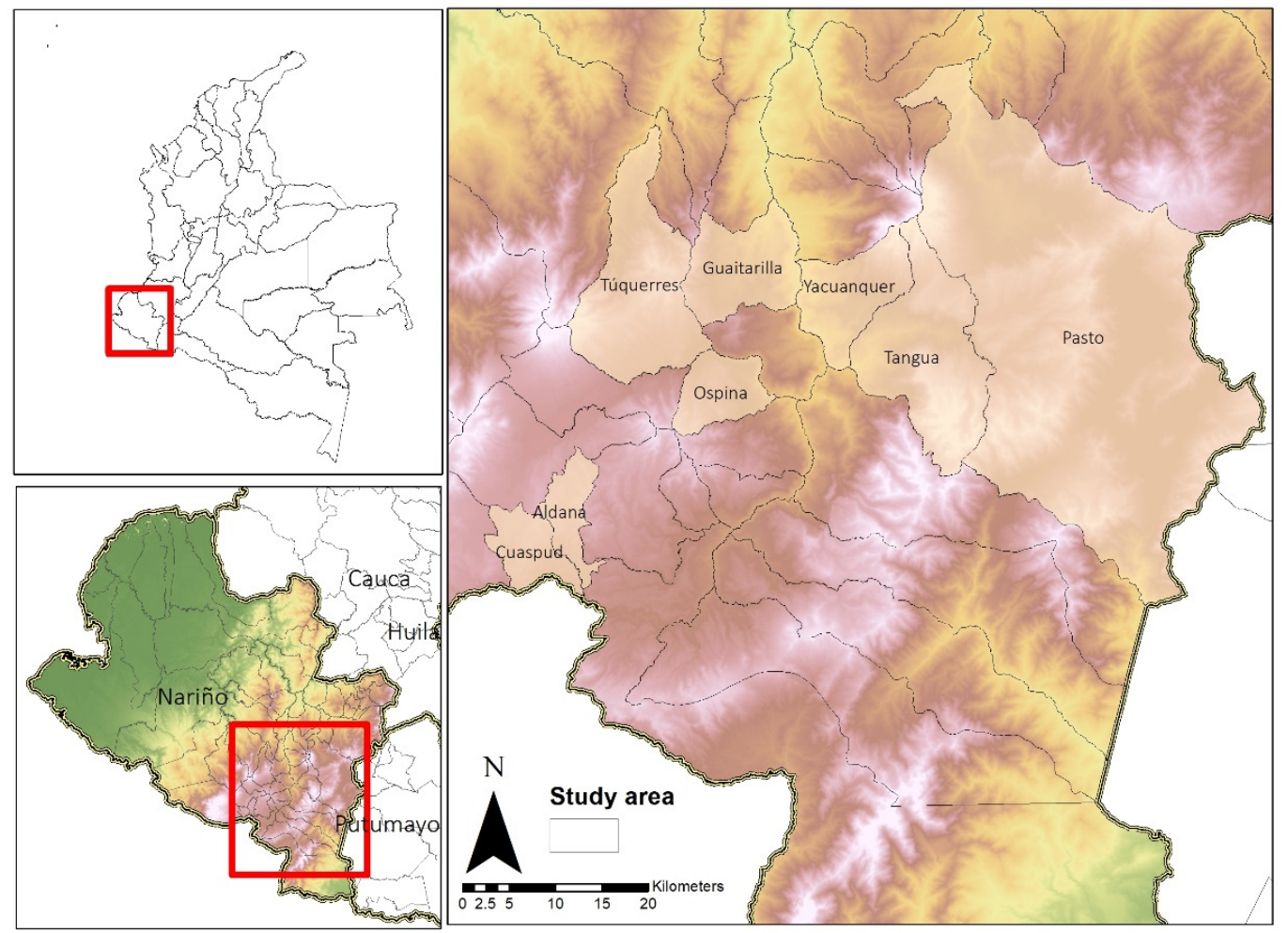

Figure 1. Study site. Municipalities (7) in Nariño, Colombia: Cuaspud (3.022 m.s.n.m.), Aldana (3.013 m.s.n.m.), Ospina (2.906 m.s.n.m.), Guaitarilla (2.635 m.s.n.m.), Tangua (2.436 m.s.n.m.), PastoSocorro (2.527 m.s.n.m.), and Yacuanquer (2.670 m.s.n.m.).

\subsection{Data Collection}

A series of 11 complete workshops (one or two sessions per workshop) were performed in each location. A total of 252 potato growers attended, but only 112 participants completed the resilience assessment evaluation $(n=112)$. The whole process lasted one year, starting on 10 October 2017 and finishing on 15 September 2018. Data analysis was performed from this date until September 2019. A final meeting to share the results with the stakeholders (farmers, academics, industry, and government agencies) was held in March 2019. The call for the project was made via three routes: (1) agricultural offices in each municipality, (2) technical assistance municipality units (UMATAs), and (3) potato producer organizations representatives. A purposeful expert sampling was carried out since the aim of this study was to examine Nariño producers' thoughts and perceptions about resilience in their crops (their main livelihood). The sample consisted of experienced potato growers who voluntarily expressed their interest in joining the project (for which informed consent 
stating their approval was requested). Only those duly registered in the organizations or municipalities were allowed to participate.

For the SER assessment, the "toolkit for the indicators of resilience", was adopted. This detailed methodology was proposed by the United Nations University and its Institute for the Advanced Study of Sustainability (UNU-IAS), Biodiversity International, the Institute for Global Environmental Strategies (IGES), and the United Nations Development Programme (UNDP) [28]. Participants answered 20 guiding questions related to the factors examined, with some questions modified due to study area context specifics. The questionnaire structure can be found in Figure 2, Appendix A (Table A1). Participatory techniques such as social cartography, stakeholders' mapping, sociograms, and timeline assessments were also performed to generate collective reflection on resilience and landscape management.
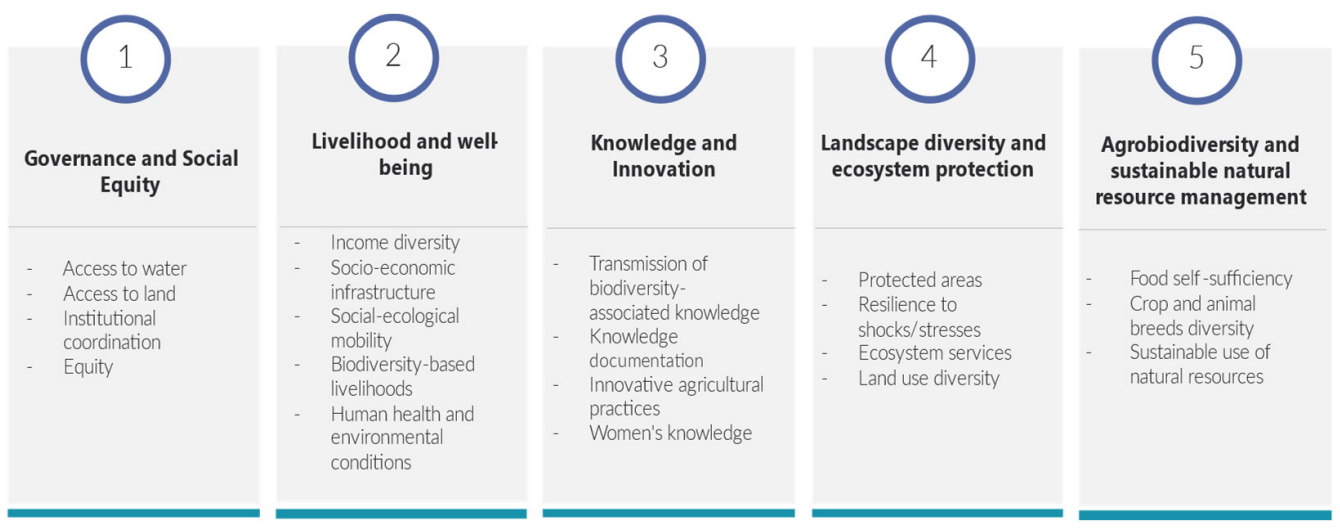

Figure 2. SER assessment structure. The factors ((1) governance and social equity, (2) livelihood and well-being, (3) knowledge and innovation, (4) landscape diversity and ecosystem protection, and (5) agrobiodiversity and sustainable natural resource management) and their corresponding indicators were modified and adapted from the methodology proposed by UNU-IAS, Biodiversity International, IGES, and UNDP [28].

Following the methodology proposed, scores were calculated and averaged. Participants evaluated each indicator from 1 to 5 , with 1 being low performance and 5 being extremely good performance [28]. Means and standard deviations (SD) were estimated from individual scores (each indicator and municipality). Calculations were made in Excel ${ }^{\circledR}$ for Microsoft 365 MSO (Version 2111). Scores can be found in Appendix A (Tables A2 and A3). Information that documents the information provided is available.

\section{Results}

\subsection{Governance and Social Equity}

The score obtained for governance and social equity was $2.8 \pm 1.1$ (Figure 3, Table A2), with a range from $1.9 \pm 0.9$ in Tangua and Yaquanquer to $3.4 \pm 1.2$ in Aldana (Table A2). This value, trending towards neutral to low, evidences the need to strengthen management capacities and internal/external relationships within territories.

Access to water (i.e., governance), understood as the social ecological systems that regulate and guarantee equity and efficiency in water access and distribution, is a critical point among growers. Producers scored it with $2.4 \pm 1.0$. and listed the following matters as major issues: water deficits, institutional inefficiency to distribute and manage the resource, community inability to equitably distribute water resources, and insufficient infrastructure for equitable water distribution (Figure 4, Table A3).

Water access in the Tangua region obtained the lowest score for this metric with a value of $1.3 \pm 0.6$. This population has experienced drought crises without any contingency or action plan to recover from them (Figure 4, Table A3). Here, the resources have been unevenly distributed, with producers with higher incomes monopolizing access to 
water sources, leaving most of the population without this essential resource. This value corresponds with their direr narratives.

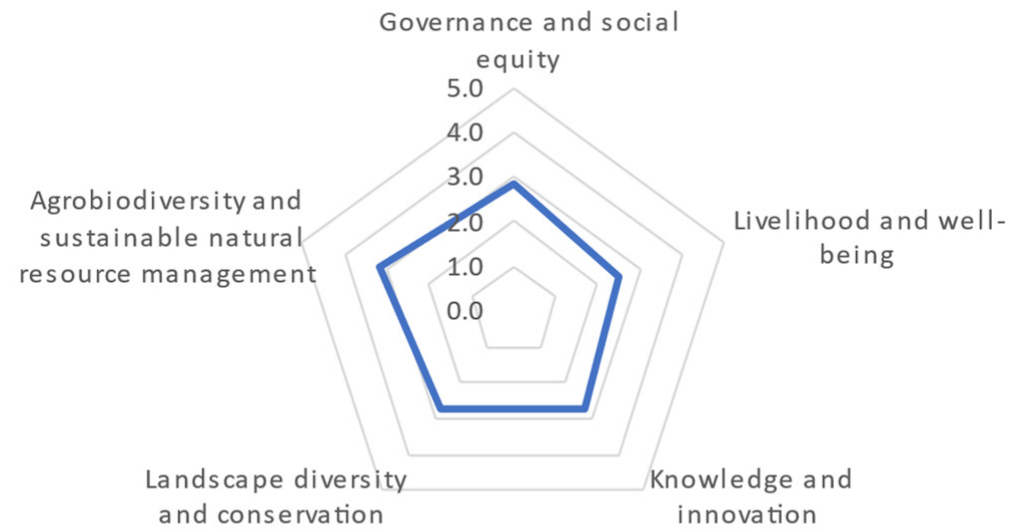

Figure 3. General scores for the main factors considered in the assessment of SER in potato-producing crops in the Nariño region (southwestern of Colombia). The results were calculated and averaged ( 1 being low performance and 5 extremely good performance). Details about means and SD can be found in Appendix A (Table A2). Methodology adapted from UNU, IAS, Biodiversity International, IGES, and UNDP [28].

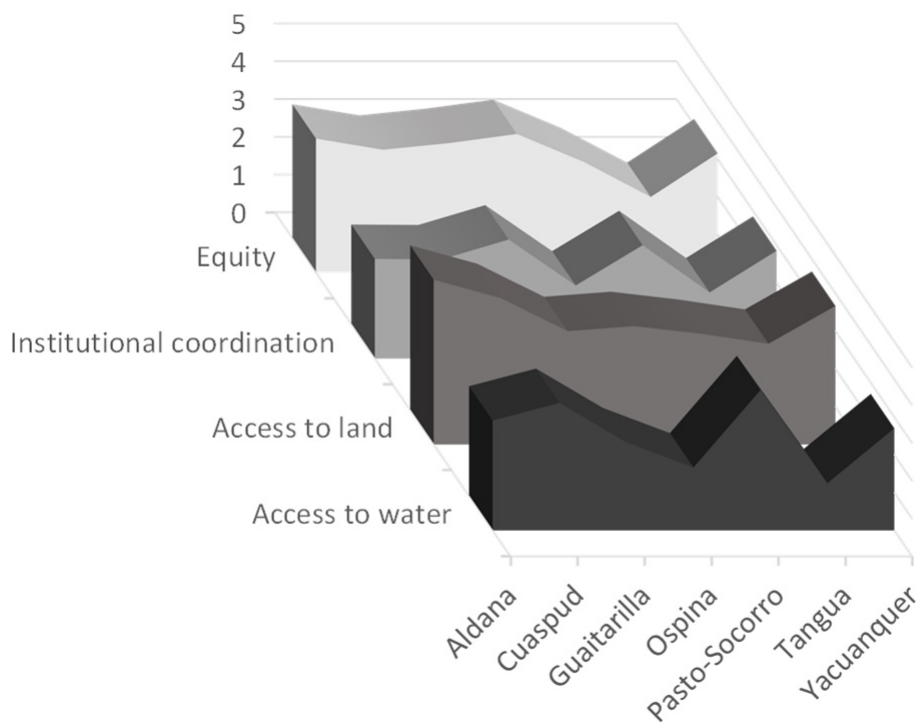

Figure 4. Governance and social equity. Relative comparison of scores provided by potato producers in each municipality. Participants evaluated each indicator from 1 to 5 ( 1 being low performance and 5 extremely good performance). The results were calculated and averaged. Details about means and SD can be found in Appendix A (Table A3).

Institutional coordination, another critical indicator of governance, obtained an average score of $2.5 \pm 1.1$. Via sociogram and stakeholder mapping, participants reported gaps in the projects implemented by different institutions. This is due to continuous changes in their leadership, which have negatively affected the implementation of participatory governance mechanisms and, consequently, the decision-making process in favor of these communities. The lowest scores were from Tangua and Ospina (1.8 \pm 1.0 and $1.9 \pm 0.6$, respectively) (Figure 4, Table A3). In the latter, institutional interventions were carried out, but processes lack continuity, which has diminished their credibility and legitimacy. Associations and collaborative initiatives that promote local governance are scarce, increasing the dependence on institutional assistance. 
Access to land and equity score averaged $3.3 \pm 0.9$ and $3.1 \pm 1.1$, respectively (Figure 4 , Table A3). Participants own small farms, but most of them do not have property rights, and it is unknown if their properties are legally deeded. Recently, land leasing has prevailed as a new livelihood strategy for large-scale producers. It fosters intensive monocultures and, therefore, does not support the sustainable development of this territory. Regarding equity, participants did not feel they were discriminated against and described their participatory activities as equitable in terms of access and opportunities. The exception for this was Tangua, where producers felt isolated and excluded (Figure 4).

\subsection{Livelihood and Well-Being}

The average score for this factor in all municipalities was $2.5 \pm 1.1$ (Figure 3, Table A2), with values ranging from $2.2 \pm 1.3$ in Tangua to $2.9 \pm 1.0$ in Cuaspud and Aldana (Table A2). One of the most critical aspects regarding "livelihood and well-being" is the absence of bio-industries that allow producers to take advantage of their agricultural biodiversity $(2.1 \pm 1.3)$ (Figure 5, Table A3). Farmers do not know how to identify new business initiatives or livelihood strategies to add value to their agricultural products. Their households widely depend on dairy farming and potato crops. Their livelihood portfolio is limited, which correlates with the lack of non-agricultural job opportunities (2.2 \pm 1.1 ) (Figure 5, Table A3).

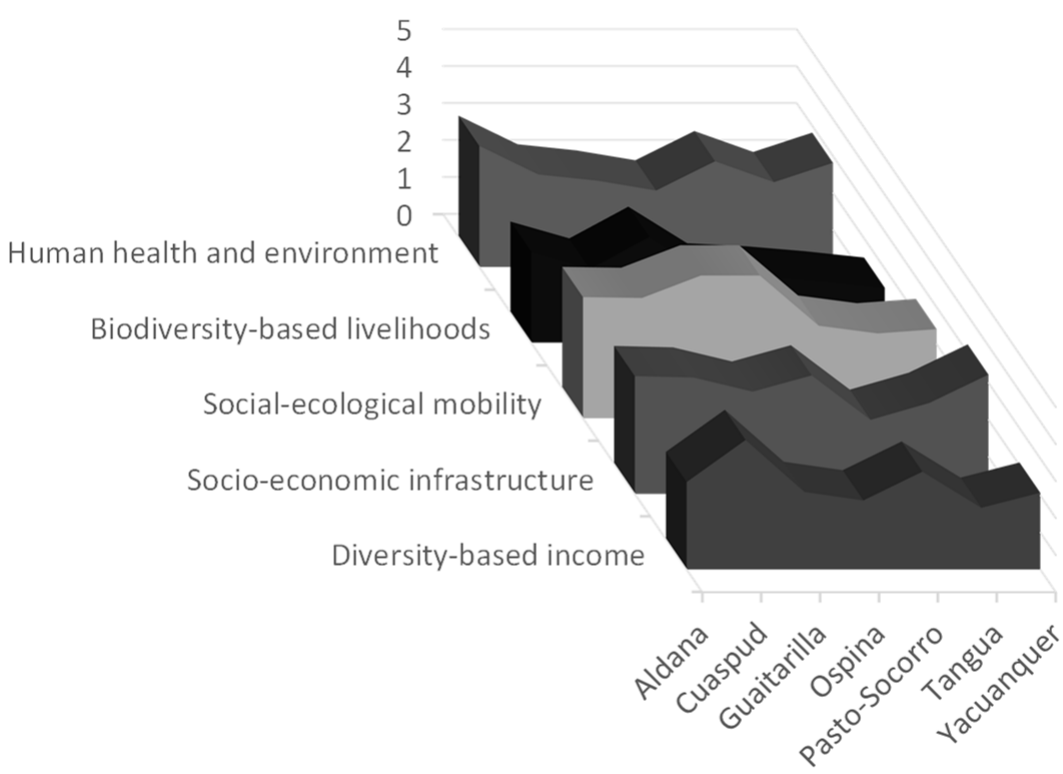

Figure 5. Livelihood and well-being. Relative comparison of scores provided by potato producers in each municipality. Participants evaluated each indicator from 1 to 5 ( 1 being low performance and 5 extremely good performance). The results were calculated and averaged. Details about means and SD can be found in Appendix A (Table A3).

Participants indicated that they are able to replace crops or economic activities $(3.0 \pm 1.1)$ (Figure 5, Table A3). However, based on previous experiences (i.e., the switch from cereals to potato carried out in this territory), they recognize that the process is challenging, and they are afraid of facing the uncertainty that this change could generate in their livelihood. On the other hand, participants also noted deficits in infrastructure. For them, the current infrastructure is inadequate or insufficient to meet their daily requirements $(2.8 \pm 0.9)$ (Figure 5, Table A3).

When it comes to well-being, the relationship between natural resources and people's health status received a score of $2.6 \pm 1.0$ (Figure 5, Table A3). According to participants, this is a major issue in their region, and it is related to spraying excessive amounts of agrochemicals in their crops and the absence of sewerage and basic sanitation systems, which negatively affects their welfare. 


\subsection{Knowledge and Innovation}

The average score for this factor in all municipalities was $2.7 \pm 1.2$. (Figure 3, Table A2). Transmission of local knowledge and documentation was cited as critical points in this section ( $2.6 \pm 1.0$ and $1.9 \pm 1.1$, respectively). According to potato producers, very few efforts were made to retrieve local and ancestral knowledge regarding potato growing strategies, medicinal, or gastronomic uses (Figure 6, Table A3).

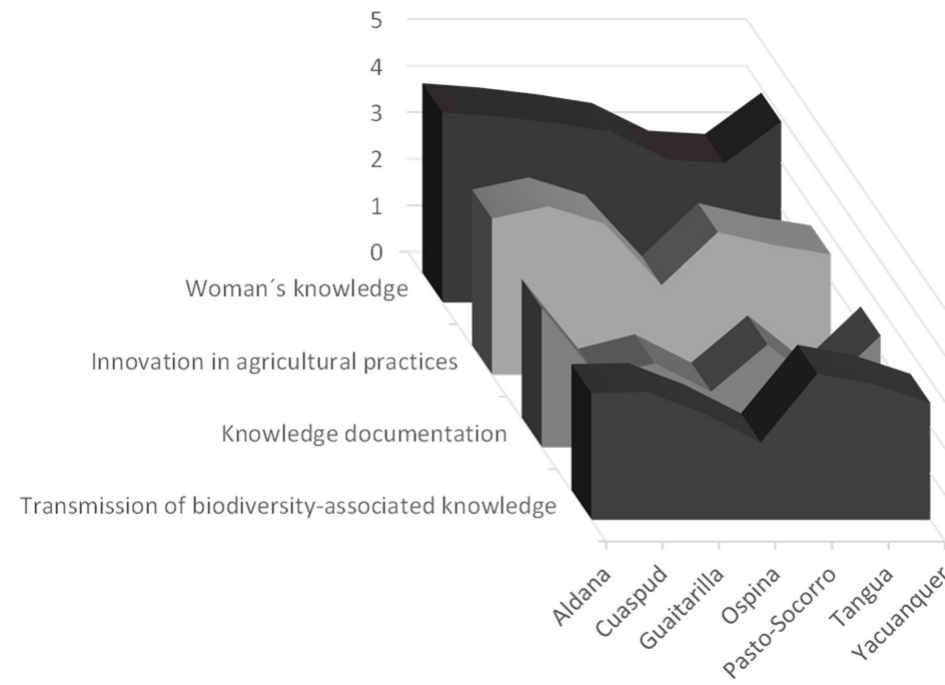

Figure 6. Knowledge and innovation. Relative comparison of scores provided by potato producers in each municipality. Participants evaluated each indicator from 1 to 5 ( 1 being low performance and 5 extremely good performance). The results were calculated and averaged. Details about means and SD can be found in Appendix A (Table A3).

They also highlight the fact that spaces that promote dialogue between generations (i.e., transferring knowledge from the oldest to the youngest) are disappearing. This is contributing to the loss of identity and motivation to settle down in these territories affecting generational replacement processes, especially in younger individuals.

Women's knowledge and influence on decision making (at household, farm, and municipality levels) was highly rated (3.6 \pm 0.9$)$ (Figure 6, Table A3). This is in contrast to the trend of making women's work invisible. Women do not get monetarily compensated for their work and are not recognized as the main actors in this productive system (Figure 6, Table A3).

Agricultural innovation in all municipalities received a score of $2.9 \pm 0.9$. Producers cited lack of access to technology. Technical assistance coverage is very low, and recommendations in this regard are provided by input sale representatives. Rural education in this region is also not robust, nor does it have the required curriculum rigor to meet the demands of younger constituents (Figure 6, Table A3).

\subsection{Landscape Diversity and Ecosystem Protection}

The score for this factor was $2.8 \pm 1.0$, indicating that it has room for growth before reaching its optimum (Figure 3, Table A2). The lowest scores were related to resilience $(2.5 \pm 1.0)$, ecosystem services $(2.5 \pm 0.9)$, and ecosystem conservation (i.e., protected areas) $(2.6 \pm 1.0)$ (Figure 7 , Table A3). Through a multiple-choice exercise, producers associated forest and páramo habitats with clean water resources, clean air resources, wood resources, flood control, and biodiversity conservation areas, whereas agroecosystems were associated with soil fertility and food availability. Education and recreational activities were associated with urbanization. Producers mentioned that forests and páramos are not properly protected, and there are not enough to sustainably supply the population's necessities, such as water and wood. 


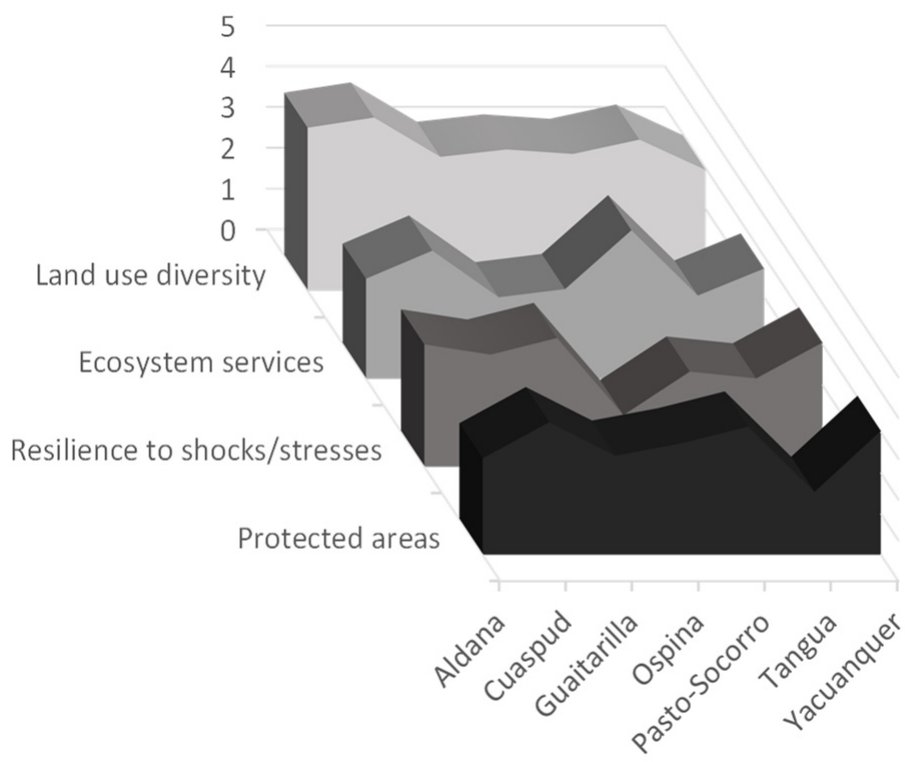

Figure 7. Landscape diversity and conservation. Relative comparison of scores provided by potato producers in each municipality. Participants evaluated each indicator from 1 to 5 (1 being low performance and 5 extremely good performance). The results were calculated and averaged. Details about means and SD can be found in Appendix A (Table A3).

Regarding environmental resilience, one of the main concerns mentioned was climate change. Most of the producers do not have access to irrigation systems, and their planting calendars are synchronized with the beginning of the rainy season. Their concerns about changing weather patterns arise from this narrative. The probability of crop losses and failure due to droughts or floods has drastically increased. Accordingly, their capacity to react to frost and hailstorms is minimal. These conditions have forced them to rethink and pursue alternatives to generate income, such as dairy farming as a livelihood strategy.

Land use diversity obtained a score of $3.5 \pm 0.8$, which could be considered "moderate" to "good" (Figure 7, Table A3). This qualification is based on this region's diverse environments that still cover large areas. However, the participants acknowledge that this aspect could improve considering the potential for diversification of this territory.

\subsection{Agrobiodiversity and Sustainable Natural Resource Management}

This factor scored a $3.2 \pm 1.1$ (Figure 3, Table A2), with the sustainable use of natural resources the lowest indicator $(2.9 \pm 1.1)$, followed by crop-animal breeds diversity $(3.3 \pm 1.1)$ and then food autonomy (3.4 \pm 1.1$)$ (Figure 8, Table A3). Agrochemical intensive applications and erosion were noted as the attributes that affect the sustainability of this system.

Focusing potato production on a few varieties/cultivars has also negatively affected the diversity of products in the region. Nevertheless, being in the Andes provides advantages, such as a variable climate that allows farmers to grow different crops depending on the season (as extracted from the stakeholder mapping exercise). Such heterogeneity could be improved through crop diversification programs that would expand producers' livelihood strategies. Producers are especially interested in establishing cold-climate vegetable and fruit crops.

Local government's initiatives to improve sustainability included the collection of agrochemical packages/containers and training programs on "good agricultural practices". 


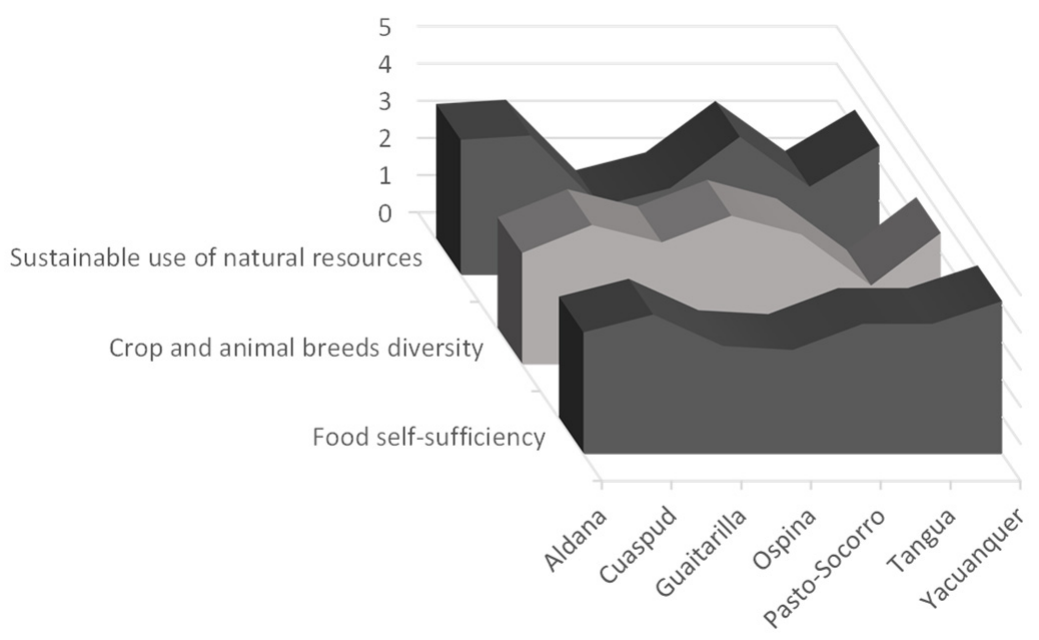

Figure 8. Biodiversity. Relative comparison of scores provided by potato producers in each municipality. Participants evaluated each indicator from 1 to 5 ( 1 being low performance and 5 extremely good performance). The results were calculated and averaged. Details about means and SD can be found in Appendix A (Table A3).

\section{Discussion}

This work collected qualitative information to assess resilience in a potato cropping system in Nariño, Colombia. As expected, in a subsistence farming scheme such as the one examined, we documented limited and insufficient SER. Building ecosystem services management strategies in this area requires understanding its landscape and governance structure. Therefore, local stakeholders are the best indicators in charge of reflecting and acting on their own territories. In this sense, this study was a good fit to mobilize the community towards the design of strategies that allow them to promote collective actions to enable positive change.

That is why our approach prioritized producers' thoughts, perceptions, needs, and beliefs (man-nature interactions), which differs from methodologies focused on sociotechnical [39], agricultural [40-43], or resilience environmental aspects [44,45]. Thus, the information obtained herein constitutes a baseline for producers to design for themselves a strategic plan to self-manage their territory and promote resilience.

In Colombia, very few attempts have been made to address this kind of analysis, but see [31], which evaluated resilience in six farms in the Antioquia region and the Satoyama initiative [37], assessing SER in "Las Cruces", Santander (area affected by armed conflict). Hence, these findings are novel and provide several noteworthy contributions to SER assessments in high mountain productive systems in the country and Latin America in general.

\subsection{Governance and Social Equity}

The lower scores assigned to this category indicate the need to strengthen public policies, agreements, and institutional processes that govern/regulate access to natural resources (i.e., water and land as priority). People are experiencing water shortages and other environmental difficulties due to climate change, habitat fragmentation/degradation, and uneven resources distribution. This generates social-environmental conflicts among stakeholders. In this context, governmental and community-based organizations should work together to align their actions to ensure equitable access and efficiency in natural resource use.

For water, in particular, irrigation and rural aqueduct boards should embrace collaborative initiatives to guarantee supply and increased coverage. Accordingly, producers' water management strategies are required, but technical assistance (that corresponds to the system's requirements) should be provided [40]. Water irrigation systems increase 
resilience by allowing growers to modify their sowing and harvesting dates. Hence, by guaranteeing constant potato production, market saturation and prices instability can be prevented, e.g., see [46].

Since land rights are not recognized, growers cannot access credits or subsidies. For these low-income areas, special financing plans must be implemented, as suggested by [47]. Hence, the entire financial and economic system should be designed for a population whose livelihood asset lies on ecosystem services and human capital instead of monetary capacity, as highlighted by [39] in their work evaluating agricultural value chains in New Zealand.

Further, when public and private institutions do not work collaboratively, resulting in functional overlap generating multiple planning tools, initiatives, and projects, this ends up negatively impacting community engagement. As a result, continuity in long-term interventions is lacking, eroding producers' trust in these initiatives. This situation needs to be corrected with new collaborative plans designed and implemented over the long term.

Regarding equity, while producers affirmed they do not feel discrimination, based on their narratives, inequities against women and indigenous groups are still common, particularly in Tangua, where almost the entire population is composed of indigenous groups. Unfortunately, the current study was unable to evaluate gender equity, but this aspect should be addressed in further initiatives since women play an important role in the potato production process even though their work goes unappreciated. In this regard, the study performed by [48] with productive communities in Africa offers a model that would be interesting to replicate in Latin America.

\subsection{Livelihood and Well-Being}

Following the well-being framework proposed by [49], this factor should consider three dimensions: material, relational, and subjective. The material was rated very low in our study. It is directly related to income, wealth, livelihood assets, and physical health. According to the producers' accounts, the main issue about their economic/monetary capacity is not their income but their limited access to new markets or bio-industries. This is an example of how increased well-being does not always correspond to increased resilience [50]. Undoubtedly, new strategies are required to make this system more efficient, and although producers are willing to implement changes, they are afraid of failing in the process since they lack help and direction in implementing a conversion, as documented with other agricultural transitions previously stated.

Only timely and coordinated interventions led by social organizations or institutions allow growers to design action plans that positively impact population well-being. This fact, though, is cause for concern because the collective actions, interactions, and relationships by farmers with the establishments (public and private) have deteriorated over the years. In this regard, the Colombian government recently proposed an innovation system that aims to articulate these institutions/organizations to positively impact and increase their presence in rural areas. However, this initiative is just being implemented [38,51].

The farmers' narratives also touched on cultural values, norms, belief systems, and notions of self to reach well-being (aggregately being the subjective dimension). Growers recognize they are the main stewards in maintaining their quality of life; however, few request help to improve these processes. For example, farmers agreed that excessive use of pesticides is affecting people's health but were unsure how to adequately correct the problem. Although immediate and collective changes may be performed, technical assistance is insufficient. Therefore, these problems go beyond producers' knowledge and capabilities.

\subsection{Knowledge and Innovation}

This factor also obtained low scores. In general, producers want materials to educate themselves that update methodologies and technics that allow them to improve their production processes; however, there are no programs or activities that provide this benefit. Growers define the education system as deficient and detracting from their basic needs. 
This is a common sentiment in several regions of Colombia, but here, the main concern also is that the education system is not preserving the ancestral indigenous people's knowledge that inhabits these municipalities.

Beyond technological assistance towards territorial innovation systems (in which knowledge management processes can be guaranteed) should be the aim focus of any educational initiatives in this region (Minciencias 2020). Initiatives should emphasize (1) the recovery of local knowledge, (2) the promotion of spaces that facilitate the transition and sharing of ancestral knowledge, and (3) the integration of methodologies from this knowledge that allow it to be adopted by younger generations. In this way, identity and group recognition will take their rightful place in building resilience at the cultural level (Š̄ūmane et al., 2018).

To implement SER in this system implies safeguarding ecosystem services and educating stakeholders in sustainable management practices. This is challenging and requires a pedagogical approach that allows producers to broach this concept meaningfully [38]. Thus, a conceptual and methodological framework specific to this area needs to be designed. If implemented, this process should be routinely evaluated to determine this methodology's potential and find areas to improve its scope.

\subsection{Landscape Diversity and Ecosystem Protection}

SER must be addressed at different scales [19]. Although all components are interconnected, processes occurring at the local level (e.g., those related to governance over irrigation systems or educative programs in each municipality) do not necessarily mean they are important at the landscape level. Keeping the "big picture" in mind is vital for enacting methodologically sound conservation efforts. The authors of [44] mention how deforestations processes can affect temperature and rainfall regimes as well as vegetation composition. They also highlight how biodiversity losses are directly related to losses in resilience, which may eventually lead to the collapse of a system.

Coming back to our SER assessment, growers have noted these macro-scale processes in the region. They have witnessed how protected areas have diminished, biodiversity has declined, and ecosystem services have decreased. Producers are acutely aware of how these phenomena may affect their livelihoods and well-being and thus want to reverse this trend. Doing so requires making it a priority to create strategic plans that position the potato farming system as a pioneer in resource conservation, sustainability, and resilience. To achieve this goal, it is necessary to think across scales and social-ecological factors at the regional level. We see an intervention of this magnitude as the only way for producers to reconcile themselves with their territories.

\subsection{Agrobiodiversity and Sustainable Natural Resource Management}

This is another factor that concerns producers and must be analyzed at different levels. Notably, problems have been identified for (1) species: their loss is noticeable/visible; (2) potato cultivation: the focus on producing a few commercial variates has been viewed as a mistake since farmers now recognize the value of cultivar diversity in their production systems; (3) landscape: the region is home to a variety of ecosystems, which are vital water sources for the entire region, but nevertheless, these areas are disappearing; and (4) crop diversity: farmers recognize the advantages of having access to different agricultural products on their farms and across the mountain region. Altitude offers different climatic environments that provide support for various crops. However, the use of agrochemicals and erosion have deprived the land.

Despite knowing the relevance of protecting biodiversity, few actions have been taken to safeguard species richness. It has been reported that the development of opportunity crops (e.g., forage, medicinal plants, beverages, minor herbs, and spices) combined with major crops (i.e., potato) may allow humankind to achieve sustainability [52]. These alternative livelihoods may offer opportunities for new enterprises and diet diversification, especially in this region, where potato production is not only the income source but also 
a matter of food sovereignty. The research focused on this topic can then be conducted in depth.

A species genetic variability (i.e., increased number of varieties) also provides opportunities to mitigate the negative incidence caused by climate, pests, or diseases (among others adverse pressures), in a natural and efficient way. Thus, plant genetic resources and ancestral knowledge should be linked to increasing resilience at the crop level, which will ultimately also affect the landscape.

It is important to mention that gender is a key variable in protecting and promoting agrobiodiversity adaptation processes, as demonstrated by [53] in the Himalayas. Therefore, women's social-ecological status in small farming systems, such as potato in this region, must also be re-considered for meaningful change to occur.

\section{Conclusions}

This work materializes the idea of assessing resilience in a high mountain potato system from a social-ecological perspective. Resilience scored overall low to moderate, which evidences that this population-which depends almost entirely on the crop-is vulnerable to adverse events that minimize its productivity. Moreover, there are no strategies that allow farmers to face, adapt, and withstand unfavorable impacts, which also reduce the short/long-term sustainability of this productive system. Governance, pollution, sustainable livelihood assets, and well-being were deemed critical points by farmers. Nevertheless, addressing these major issues requires an approach that goes beyond technology or productivity. Instead, strategies that impact the social and natural capital at the landscape level must be implemented.

The information obtained help stakeholders to identify gaps in current initiative/policies that must be strengthened. In this sense, this study made it possible to include "building resilience" as one of the main goals of the new potato production program nationwide. This is how concerns regarding producers' well-being, for example, are now considered and translated into action plans.

This source of novel information provides the elements to design new projects and programs to improve not only resilience but the living conditions of this population. The relevance of recovering native varieties, the need to link these products with productive schemes, the urgency of integrating local knowledge, and the implementation of agroecological systems, among others, are important matters that were identified as critical and should be addressed from a transdisciplinary approach. These efforts should also support collaborative learning and horizontal dialogue to increase the participation of women and indigenous people, as they are key actors in the conservation of the natural capital of this region.

Author Contributions: Conceptualization, E.M.; methodology, E.M. and L.T.L.-M.; formal analysis, E.M. and U.V.-G.; investigation, E.M., L.T.L.-M., H.S.R.-Z. and U.V.-G.; data curation, E.M.; writing—original draft preparation, E.M., L.T.L.-M., H.S.R.-Z. and U.V.-G.; writing—review and editing, E.M. and U.V.-G.; visualization, E.M.; project administration, E.M.; funding acquisition, E.M. All authors have read and agreed to the published version of the manuscript.

Funding: This study is part of the science, technology, and innovation project "Mejoramiento Tecnológico y Productivo del Sistema Papa en el Departamento de Nariño" supported by the Science, Technology, and Innovation Fund of the Colombian general royalties' system (Code BPIN2014000100022).

Data Availability Statement: The data presented in this study are available on request from the corresponding author. The data are not publicly available due to confidentiality agreements between the participants (institutions and producers). 
Acknowledgments: We thank the Gobernación de Nariño, Corporación Colombiana de Investigación Agropecuaria (Agrosavia) and Universidad de Nariño for their support through the agreement No. 480-2015. We also like to thank producers, associations, professionals, technicians, and other institutions (from the seven municipalities) that committedly joined this initiative. Finally, we would like to thank Michael Garvey for his valuable contribution and continued support and the anonymous reviewers for their comments to help improve the manuscript.

Conflicts of Interest: The authors declare no conflict of interest.

\section{Appendix A}

Table A1. Social-ecological resilience (SER) assessment structure. Factors, indicators, and questions. Adapted and modified for this project from UNU, IAS, Biodiversity International, IGES, and UNDP [28].

\begin{tabular}{|c|c|c|}
\hline Factors & Indicators & Questions \\
\hline \multirow{4}{*}{$\begin{array}{l}\text { Governance and } \\
\text { social equity }\end{array}$} & Access to water & $\begin{array}{l}\text { Is the access to water for irrigation and human } \\
\text { consumption guaranteed, and how effective are } \\
\text { the organizations/institutions in charge of } \\
\text { ensuring/regulating this service? }\end{array}$ \\
\hline & Access to land & $\begin{array}{l}\text { Is access to land guaranteed and land titles } \\
\text { legally constituted? }\end{array}$ \\
\hline & Institutional coordination & $\begin{array}{l}\text { Is there connection, coordination, and cooperation } \\
\text { within and between institutions, families, and } \\
\text { individuals for the management of their territory? }\end{array}$ \\
\hline & Equity & $\begin{array}{l}\text { Is the access to opportunities and resources } \\
\text { (i.e., education, health, employment, credits, land, } \\
\text { water, housing) equitable if the population belongs } \\
\text { to a group of young or old people, women, } \\
\text { indigenous, or Afro-descendants, among others? }\end{array}$ \\
\hline \multirow{5}{*}{$\begin{array}{l}\text { Livelihood and } \\
\text { well-being }\end{array}$} & Diversity-based income & $\begin{array}{l}\text { Besides agriculture, what kind of } \\
\text { income-generating activities prevail in the } \\
\text { community? These may include agribusiness, } \\
\text { commerce, transportation, handicrafts, } \\
\text { construction, mining, or external income } \\
\text { (i.e., day labor, formal employment). }\end{array}$ \\
\hline & Socio-economic infrastructure & $\begin{array}{l}\text { Does the socio-economic infrastructure match the } \\
\text { needs of the community? }\end{array}$ \\
\hline & Social-ecological mobility & $\begin{array}{l}\text { Are people in the region able to switch their } \\
\text { productive activities if required (including a } \\
\text { reallocation to generate new-income sources)? }\end{array}$ \\
\hline & Biodiversity-based livelihoods & $\begin{array}{c}\text { Does biodiversity (including agrobiodiversity) } \\
\text { generate/support/promote new products, } \\
\text { businesses, or services in the territory? }\end{array}$ \\
\hline & $\begin{array}{l}\text { Human health and } \\
\text { environmental conditions }\end{array}$ & $\begin{array}{c}\text { Does the environment favor good health } \\
\text { conditions in the population? } \\
\text { Is there access to drinking water and good waste } \\
\text { management and disposal? } \\
\text { Are sources of water, soil, and air pollution } \\
\text { under control? }\end{array}$ \\
\hline
\end{tabular}


Table A1. Cont.

$\begin{array}{lll}\text { Factors Indicators } & \text { Questions }\end{array}$

Transmission of biodiversity-associated knowledge

Are knowledge and traditions related to the region's biodiversity?

Is this knowledge (e.g., about native products) transmitted from the oldest to the youngest as a mechanism that promotes regional development?

Have local knowledge and traditional practices been documented in the region?

(Books or documents with knowledge

Knowledge and innovation
Knowledge documentation

Women's knowledge

recovery, identification of local knowledge

holders, resource classification systems, biodiversity registers, seasonal calendars, etc.)

Are innovative, environmentally friendly agricultural practices able to adapt to environmental or socio-economic changes implemented in the region?

Are women's experiences, skills, and knowledge about the management of their land (farm/territory) valued?

Are there areas in the landscape where native forests are protected under formal or

Protected areas informal protection schemes (national parks, forest reserves, wildlife sanctuaries, conserved community areas)?

Landscape diversity and ecosystem protection
Resilience to shocks/stresses

Ecosystem services
Are you able to face/support/recover from environmental, social, or economic shocks/stresses?

Are forest and natural areas enough to provide clean water, timber, soil stability, pest regulation, and other environmental goods needed for a farm to work in a proper way?

How is land used in the territory? Are there forests, different crops, or grasslands?

Do the community consume locally produced food?

Food self-sufficiency

Agrobiodiversity and sustainable natural resource management
How much the diet depends on local products?

Do the community consume traditional and indigenous' crop products?

What varieties of plants and animals are grown in the region/community?

Does the community use and conserve local/native/traditional animals and crops?

Is the current use of soils, water, forests, and wildlife sustainable? 
Table A2. Scores for the main factors considered in the SER assessment of potato-farming systems in seven municipalities of Nariño (Colombia). The results were calculated and averaged. Means \pm SD are presented.

\begin{tabular}{ccccccccc}
\hline Factors & Aldan & Cuasp & Guait & Ospin & Pas/So & Tangua & Yacua & Total \\
\hline Governance and & $3.4 \pm 1.2$ & $3.3 \pm 1.2$ & $3.0 \pm 0.9$ & $2.6 \pm 1.1$ & $3.1 \pm 0.9$ & $1.9 \pm 0.9$ & $1.9 \pm 09$ & $2.8 \pm 1.1$ \\
social equity & $(n=44)$ & $(n=32)$ & $(n=83)$ & $(n=60)$ & $(n=56)$ & $(n=96)$ & $(n=108)$ & $(n=108)$ \\
& $2.9 \pm 0.9$ & $2.9 \pm 1.0$ & $2.8 \pm 1.2$ & $2.6 \pm 1.0$ & $2.4 \pm 1.1$ & $2.2 \pm 1.3$ & $2.4 \pm 1.0$ & $2.5 \pm 1.1$ \\
Livelihood and well-being & $(n=55)$ & $(n=40)$ & $(n=105)$ & $(n=74)$ & $(n=70)$ & $(n=120)$ & $(n=135)$ & $(n=599)$ \\
Knowledge and & $3.3 \pm 1.1$ & $3.0 \pm 1.2$ & $2.8 \pm 1.2$ & $2.1 \pm 1.1$ & $2.9 \pm 1.1$ & $2.5 \pm 1.0$ & $2.9 \pm 1.1$ & $2.7 \pm 1.2$ \\
$\quad$ innovation & $(n=44)$ & $(n=32)$ & $(n=83)$ & $(n=60)$ & $(n=56)$ & $(n=96)$ & $(n=108)$ & $(n=479)$ \\
Landscape diversity and & $3.0 \pm 1.3$ & $3.3 \pm 0.9$ & $2.7 \pm 1.0$ & $2.4 \pm 1.0$ & $3.1 \pm 1.1$ & $2.4 \pm 1.0$ & $2.9 \pm 0.7$ & $2.8 \pm 1.0$ \\
ecosystem protection & $(n=42)$ & $(n=32)$ & $(n=82)$ & $(n=60)$ & $(n=54)$ & $(n=96)$ & $(n=103)$ & $(n=469)$ \\
Agrobiodiversity and & $3.3 \pm 0.6$ & $3.8 \pm 0.9$ & $2.7 \pm 1.1$ & $3.0 \pm 1.1$ & $3.6 \pm 1.0$ & $2.7 \pm 1.1$ & $3.7 \pm 0.9$ & $3.2 \pm 1.1$ \\
$\quad$ sustainable natural & $(n=33)$ & $(n=24)$ & $(n=63)$ & $(n=45)$ & $(n=42)$ & $(n=72)$ & $(n=81)$ & $(n=360)$ \\
resource management & & & & & & & & \\
\hline
\end{tabular}

Table A3. Scores for each indicator considered in the SER assessment of potato-farming systems in seven municipalities of Nariño, Colombia. Participants evaluated each indicator from 1 to 5 (1 being low performance and 5 extremely good performance). The results were calculated and averaged. Means \pm SD are presented.

\begin{tabular}{|c|c|c|c|c|c|c|c|c|c|c|c|c|c|c|c|c|c|c|c|c|c|c|c|c|}
\hline \multirow[t]{2}{*}{ Factors and Indicators } & \multicolumn{3}{|c|}{ Aldana } & \multicolumn{3}{|c|}{ Cuaspud } & \multicolumn{3}{|c|}{ Guaitarilla } & \multicolumn{3}{|c|}{ Ospina } & \multicolumn{3}{|c|}{ Pasto-Socorro } & \multicolumn{3}{|c|}{ Tangua } & \multicolumn{3}{|c|}{ Yaquanquer } & \multicolumn{3}{|c|}{ Total } \\
\hline & $\bar{X}$ & $n$ & SD & $\bar{X}$ & $n$ & SD & $\bar{X}$ & $n$ & SD & $\bar{X}$ & $n$ & SD & $\bar{X}$ & $n$ & SD & $\bar{X}$ & $n$ & SD & $\bar{X}$ & $n$ & SD & $\bar{X}$ & $n$ & SD \\
\hline \multicolumn{25}{|l|}{$\begin{array}{l}\text { Governance and } \\
\text { Social Equity }\end{array}$} \\
\hline Equity & 3.5 & 11 & 1.2 & 3.3 & 8 & 0.9 & 3.4 & 21 & 1.0 & 3.7 & 15 & 0.6 & 2.9 & 14 & 1.1 & 2.0 & 24 & 0.7 & 3.3 & 27 & 1.1 & 3.1 & 120 & 1.1 \\
\hline $\begin{array}{l}\text { Institutional } \\
\text { coordination }\end{array}$ & 2.6 & 11 & 1.4 & 2.6 & 8 & 2.0 & 3.2 & 20 & 0.5 & 1.9 & 15 & 0.6 & 3.0 & 14 & 0.9 & 1.8 & 24 & 1.0 & 2.9 & 27 & 0.9 & 2.5 & 119 & 1.1 \\
\hline Access to land & 4.4 & 11 & 0.5 & 3.9 & 8 & 0.4 & 3.0 & 21 & 0.6 & 3.1 & 15 & 0.7 & 2.9 & 14 & 0.8 & 2.7 & 24 & 0.8 & 3.7 & 27 & 0.8 & 3.3 & 120 & 0.9 \\
\hline Access to water & 2.9 & 11 & 0.3 & 3.4 & 8 & 0.5 & 2.3 & 21 & 0.9 & 1.7 & 15 & 0.7 & 3.7 & 14 & 0.7 & 1.3 & 24 & 0.6 & 2.7 & 27 & 0.7 & 2.4 & 120 & 1.0 \\
\hline \multicolumn{25}{|l|}{$\begin{array}{l}\text { Livelihood and } \\
\text { well-being }\end{array}$} \\
\hline $\begin{array}{l}\text { Biodiversity-based } \\
\text { livelihoods }\end{array}$ & 2.5 & 11 & 1.0 & 2.0 & 8 & 0.9 & 2.9 & 21 & 0.9 & 1.9 & 15 & 0.6 & 1.8 & 14 & 0.7 & 2.1 & 24 & 2.2 & 1.5 & 27 & 0.6 & 2.1 & 120 & 1.3 \\
\hline $\begin{array}{l}\text { Human health and } \\
\text { environmental cond. }\end{array}$ & 3.3 & 11 & 0.6 & 2.5 & 8 & 0.5 & 2.3 & 21 & 1.1 & 2.1 & 15 & 0.6 & 2.9 & 14 & 1.4 & 2.3 & 24 & 0.9 & 2.8 & 27 & 0.8 & 2.6 & 120 & 0 \\
\hline Income diversity & 2.4 & 11 & 1.0 & 3.5 & 8 & 1.1 & 2.1 & 21 & 1.1 & 1.9 & 15 & 0.8 & 2.6 & 14 & 1.2 & 1.7 & 24 & 0.9 & 2.1 & 27 & 0.8 & 2.2 & 120 & 1.1 \\
\hline Social-ecological mob. & 3.3 & 11 & 0.6 & 3.3 & 8 & 1.2 & 3.9 & 21 & 0.9 & 3.9 & 14 & 0.8 & 2.5 & 14 & 0.9 & 2.3 & 24 & 0.8 & 2.4 & 27 & 1.2 & 3.0 & 119 & 1.1 \\
\hline Socio-economic infrastr. & 3.2 & 11 & 0.6 & 3.2 & 8 & 0.7 & 2.8 & 21 & 1.0 & 3.2 & 15 & 0.6 & 2.0 & 14 & 1.0 & 2.5 & 24 & 1.0 & 3.2 & 27 & 0.6 & 2.8 & 120 & 0.9 \\
\hline \multicolumn{25}{|l|}{$\begin{array}{l}\text { Knowledge and } \\
\text { innovation }\end{array}$} \\
\hline Innovative ag. prac & 3.4 & 11 & 0.8 & 3.6 & 8 & 0.5 & 3.3 & 20 & 0.6 & 1.9 & 15 & 0.6 & 3.1 & 14 & 0.7 & 2.8 & 24 & 0.7 & 2.6 & 27 & 1.0 & 2.9 & 119 & 0.9 \\
\hline Knowledge document. & 3.0 & 11 & 1.3 & 1.5 & 8 & 0.9 & 1.8 & 21 & 1.0 & 1.2 & 15 & 0.6 & 2.2 & 14 & 1.6 & 1.3 & 24 & 0.7 & 2.4 & 27 & 0.8 & 1.9 & 120 & 1.1 \\
\hline $\begin{array}{c}\text { Transmission of } \\
\text { biodiv-assoc. knowledge }\end{array}$ & 2.7 & 11 & 1.0 & 2.8 & 8 & 0.9 & 2.3 & 21 & 1.1 & 1.7 & 15 & 0.5 & 3.1 & 14 & 0.8 & 2.9 & 24 & 0.7 & 2.5 & 27 & 1.2 & 2.6 & 120 & 1.0 \\
\hline Women's knowledge & 4.1 & 11 & 0.7 & 4.0 & 8 & 0.8 & 3.9 & 21 & 0.8 & 3.7 & 15 & 0.8 & 3.1 & 14 & 1.1 & 3.0 & 24 & 0.7 & 3.9 & 27 & 0.8 & 3.6 & 120 & 0.9 \\
\hline \multicolumn{25}{|l|}{$\begin{array}{l}\text { Landscape diversity and } \\
\text { ecosystem protection }\end{array}$} \\
\hline Ecosystem services & 2.5 & 11 & 1.5 & 3.1 & 8 & 0.9 & 2.0 & 21 & 0.8 & 2.2 & 15 & 0.6 & 3.6 & 14 & 1.1 & 2.0 & 24 & 0.4 & 2.7 & 27 & 0.7 & 2.5 & 120 & 1.0 \\
\hline Land use diversity & 4.0 & 11 & 0.8 & 4.3 & 8 & 0.7 & 3.3 & 21 & 0.9 & 3.5 & 15 & 0.7 & 3.4 & 14 & 0.7 & 3.7 & 24 & 0.6 & 3.0 & 27 & 0.6 & 3.5 & 120 & 0.8 \\
\hline Protected areas & 2.4 & 11 & 1.0 & 3.3 & 8 & 0.7 & 2.4 & 21 & 0.9 & 2.7 & 15 & 0.5 & 3.1 & 14 & 1.0 & 1.5 & 24 & 0.6 & 3.0 & 27 & 0.9 & 2.6 & 120 & 1.0 \\
\hline Resilience to shocks & 3.0 & 9 & 1.0 & 2.8 & 8 & 0.5 & 3.2 & 19 & 0.7 & 1.3 & 15 & 0.6 & 2.3 & 12 & 1.2 & 2.2 & 24 & 0.7 & 3.0 & 22 & 0.6 & 2.5 & 109 & 1.0 \\
\hline \multicolumn{25}{|l|}{$\begin{array}{l}\text { Agrobiodiversity and } \\
\text { sustainable natural } \\
\text { resource management }\end{array}$} \\
\hline Crop-animal breeds div. & 3.0 & 11 & 0.6 & 3.8 & 8 & 0.9 & 3.3 & 21 & 0.9 & 4.0 & 15 & 0.9 & 3.5 & 14 & 1.0 & 2.1 & 24 & 1.0 & 3.6 & 27 & 0.9 & 3.3 & 120 & 1.1 \\
\hline Food self-sufficiency & 3.3 & 11 & 0.5 & 3.8 & 8 & 1.2 & 2.9 & 21 & 1.1 & 2.8 & 15 & 0.9 & 3.5 & 14 & 1.1 & 3.5 & 24 & 0.8 & 4.1 & 27 & 1.1 & 3.4 & 120 & 1.1 \\
\hline Sustainable use nat. res. & 3.6 & 11 & 0.7 & 3.8 & 8 & 0.9 & 1.9 & 21 & 0.8 & 2.3 & 15 & 1.0 & 3.7 & 14 & 1.0 & 2.4 & 24 & 0.8 & 3.5 & 27 & 0.7 & 2.9 & 120 & 1.1 \\
\hline
\end{tabular}




\section{References}

1. Gobernación de Nariño, Secretaría de Agricultura Departamental. Plan Departamental de Extensión Agropecuaria. San Juan de Pasto, Colombia. 2019; 222p. Available online: https://www.minagricultura.gov.co/ministerio/direcciones/Documents/ PDEA \%27s\%20Aprobados/PDEA\%20Nari\%C3\%B1o.pdf (accessed on 13 October 2021).

2. Enríquez, M.; Panesso, F.; Santacruz, A.; Jaramillo, V.; Ruano, E.; Timarán, A.; Suárez, J.; Chamorro, S.; Benavides, P.; Rojas, E.; et al. Estudio Prospectiva Laboral Cualitativa del Cultivo de la papa en el Departamento de Nariño. Editorial Imprenta Nacional. 2013. Available online: http:/ / cedre.udenar.edu.co/portfolio/estudio-prospectivo-laboral-cualitativo-del-cultivo-de-la-papa-en-eldepartamento-de-narino-colombia/ (accessed on 20 October 2021).

3. Hosfstede, R. El Manejo del Páramo como Ecosistema Estratégico. 2001, pp. 297-305. Available online: https://www.portalces org/sites/default/files/references/096_Hofstede\%202001\%20Paramo\%20Ecuador\%20Manejo\%2Bde \%2Bp \%C3\%A1ramo\% 2Bcomo\%2Becosistema\%2Bestrat\%C3\%A9gico.pdf (accessed on 22 October 2021).

4. Sarmiento, L.; Smith, J.K.; Márquez, N.; Escalona, A.; Erazo, M.C. Constraints for the restoration of tropical alpine vegetation on degraded slopes of the Venezuelan Andes. Plant Ecol. Divers. 2015, 8, 277-291. [CrossRef]

5. Otero, J.D.; Figueroa, A.; Muñoz, F.A.; Peña, M.R. Loss of soils and nutrients by Surface runoff in two agro-ecosystems within an Andean páramo area. Ecol. Eng. 2011, 37, 2035-2043. [CrossRef]

6. González-Martínez, M.D.; Huguet, C.; Pearse, J.; McIntyre, N.; Camacho, L.A. Assessment of potential contamination of Páramo soil and downstream water supplies in a coal-mining region of Colombia. Appl. Geochem. 2019, 108, 104382. [CrossRef]

7. Martínez, D.; López, G.; Trejos, C. Logros y retos de la cadena productiva de la papa en el municipio de Pasto. Rev. Estrateg. Organ. 2014, 3, 211-223. [CrossRef]

8. Barrientos, J.C.; Ñustes, C.E. Difusión de seis nuevas variedades de papa en Boyacá y Cundinamarca (Colombia) entre 2003 y 2010. Rev. Colmb. Cienc. Hortic. 2014, 8, 126-147. [CrossRef]

9. Fonte, S.; Vanek, S.J.; Oyarzun, P.; Quintero, D.C.; Rao, I.M.; Lavelle, P. Pathways to agroecological intensification of soil fertility management by smallholder farmers in the Andean highlands. Adv. Agron. 2012, 116, 125-184. [CrossRef]

10. Von Stackelberg, K. Ecosystem Resilience on Human Terms. Integr. Environ. Assess. Manag. 2018, 14, 598-600. [CrossRef]

11. Virapongse, A.; Brooks, S.; Metcalf, E.C.; Zedalis, M.; Gosz, J.; Kliskey, A.; Alessa, L. A social-ecological systems approach for environmental management. J. Environ. Manag. 2016, 178, 83-91. [CrossRef] [PubMed]

12. Berkes, F. Environmental governance for the anthropocene? Social-ecological systems, resilience, and collaborative learning. Sustainability 2017, 9, 1232. [CrossRef]

13. Sellberg, M.; Ryan, P.; Borgström, S.T.; Norström, A.V.; Peterson, A.D. From resilience thinking to Resilience Planning: Lessons from practice. J. Environ. Manag. 2018, 217, 906-918. [CrossRef] [PubMed]

14. Innes, J.E.; Booher, E.D. Planning with Complexity. An Introduction to Collaborative Rationality for Public Policy, 2nd ed.; Routledge: New York, NY, USA, 2010; pp. 164-199.

15. Šūmane, S.; Kunda, I.; Knickel, K.; Strauss, A.; Tisenkopfs, T.; des los Rios, I.; Rivera, M.; Chebach, T.; Ashkenazy, A. Local and farmers' knowledge matters! How integrating informal and formal knowledge enhances sustainable and resilient agriculture. J. Rural Stud. 2018, 59, 232-241. [CrossRef]

16. King, M.; Renó, V.F.; Novo, E.M.L.M. The concept, dimensions and methods of assessment of human well-being within a socioecological context: A literature review. Soc. Indic. Res. 2013, 116, 681-698. [CrossRef]

17. Stone-Jovicich, S. Probing the interfaces between the social sciences and social-ecological resilience: Insights from integrative and hybrid perspectives in the social sciences. Ecol. Soc. 2015, 20, 25. [CrossRef]

18. Ostrom, E. A diagnostic approach for going beyond panaceas. Proc. Natl. Acad. Sci. USA 2007, 104, 15181-15187. [CrossRef]

19. Ostrom, E. A general framework for analyzing sustainability of social-ecological systems. Science 2009, 325, 419-422. [CrossRef]

20. Wilkinson, C. Social-ecological resilience: Insights and issues for planning theory. Plan. Theory 2012, 11, 148-169. [CrossRef]

21. Binder, C.R.; Hinkel, J.; Bots, P.W.G.; Pahl-Wostl, C. Comparison of frameworks for analyzing social-ecological systems. Ecol. Soc. 2013, 18, 26. [CrossRef]

22. Fischer, J.; Gardner, T.A.; Bennett, E.M.; Balvanera, P.; Biggs, R.; Carpenter, S.; Daw, T.; Folke, C.; Hill, R.; Hughes, T.P.; et al. Advancing sustainability through mainstreaming a social-ecological systems perspective. Curr. Opin. Environ. Sustain. 2015, 14, 144-149. [CrossRef]

23. Folke, C.; Biggs, R.; Norström, A.V.; Reyers, B.; Rockström, J. Social-ecological resilience and biosphere-based sustainability science. Ecol. Soc. 2016, 21, 41. [CrossRef]

24. Holling, C.S.; Gunderson, L.H.; Peterson, G.D. Panarchy: Understanding Transformations in Human and Natural Systems; Island Press: London, UK, 2002; pp. 25-102.

25. Walker, B.; Holling, C.S.; Carpenter, S.R.; Kinzig, A. Resilience, adaptability and transformability in social-ecological systems. Ecol. Soc. 2004, 9, 5. [CrossRef]

26. Folke, C.; Carpenter, S.R.; Walker, B.; Scheffer, M.; Chapin, T.; Rockström, J. Resilience thinking: Integrating resilience, adaptability and transformability. Ecol. Soc. 2010, 15, 20. [CrossRef]

27. Speranza, C.I.; Wiesmann, U.; Rist, S. An indicator framework for assessing livelihood resilience in the context of social-ecological dynamics. Glob. Environ. Chang. 2014, 28, 109-119. [CrossRef] 
28. UNU-IAS; Bioversity International; IGES; UNDP. Toolkit for the Indicators of Resilience in Socio-Ecological Production Landscapes and Seascapes (SEPLS). 2014. Available online: https://ias.unu.edu/en/news/news/new-toolkit-provides-indicators-ofresilience-in-socio-ecological-production-landscapes-and-seascapes.html\#info (accessed on 20 October 2021).

29. González, J.A.; Montes, C.; Rodriguez, J.; Tapia, W. Rethinking the Galapagos Islands as a complex social-ecological system: Implications for conservation and management. Ecol. Soc. 2008, 13, 13. [CrossRef]

30. Fallas, G.; Chacón, M.; Castro, J. Sostenibilidad de sistemas agrícolas de fincas ecológicas y tradicionales en Costa Rica. Cuad. Investig. UNED 2009, 1, 151-161. [CrossRef]

31. Henao-Salazar, A. Propuesta metodológica de medición de la resiliencia agroecológica en sistemas socio-ecológicos: Un estudio de caso en los Andes Colombianos. Rev. Agroecol. 2013, 8, 85-91.

32. Casimiro-Rodriguez, L.; Casimiro-Gonzalez, J.A.; Suárez-Hernández, J.; Martín-Martín, G.J.; Navarro-Boulandier, M.; RodriguezDelgado, I. Evaluación de la resileincia socioecológica en escenarios de agricultura familiar en cinco provincias de Cuba. Pastos Forrajes 2020, 43, 304-314.

33. Huber-Sannwald, E.; Palacios-Ribeiro, M.; Arredondo-Moreno, J.T.; Braasch, M.; Martinez-Peña, R.M.; García de Alba Verduzco, J.; Monsalvo-Santos, K. Navigating challenges and opportunities of land degradation and sustainable livelihood development in dryland social-ecological systems: A case study from Mexico. Philos. Trans. R. Soc. B 2012, 367, 3158-3177. [CrossRef] [PubMed]

34. Perz, S.; Cabrera, L.; Carvalho, L.A.; Castillo, J.; Chacacanta, R.; Cossio, R.; Frnaco-Solano, F.; Hoelle, J.; Perales, L.M.; Puerta, I.; et al. Regional integration and local change: Road paving, community connectivity, and social-ecological resilience in a tri-national frontier, southwestern Amazonia. Reg. Environ. Chang. 2012, 12, 35-53. [CrossRef]

35. Delgado-Serrano, M.d.M.; Oteros-Rozas, E.; Vanwildemeersch, P.; Ortíz-Guerrero, C.; London, S.; Escalante, R. Local perceptions on social-ecological dynamics in latin america in three community-based natural resource management systems. Ecol. Soc. 2015, 20, 24. [CrossRef]

36. Pischke, E.; Mesa-Jurado, M.A.; Eastmond, A.; Abrams, J.; Halvorsen, K.E. Community perceptions of socioecological stressors and risk-reducing strategies in Tabasco, Mexico. J. Environ. Stud. Sci. 2018, 8, 441-451. [CrossRef]

37. Dunbar, W.; Subramanian, S.M.; Matsumoto, I.; Natori, Y.; Dublin, D.; Bergamini, N.; Mijatovic, D.; González, A.; Yiu, E.; Ichikawa, K.; et al. Lessons Learned from Application of the "Indicators of Resilience in Socio-ecological Production Landscapes and Seascapes (SEPLS)" under the Satoyama Initiative. In Managing Socio-Ecological Production Landscapes and Seascapes for Sustainable Communities in Asia; Saito, O., Subramanian, S., Hashimoto, S., Takeuchi, K., Eds.; Science for Sustainable Societies Springer: Singapore, 2020; pp. 93-116. [CrossRef]

38. Allen, K.E.; Castellano, C.; Pessagno, S. Using dialogue to contextualize culture, ecosystem services, and cultural ecosystem services. Ecol. Soc. 2021, 26, 7. [CrossRef]

39. Aboah, J.; Wilson, M.M.J.; Rich, K.M.; Lyne, M.C. Operationalizing resilience in tropical agricultural value chains. J. Supply Chain Manag. 2019, 24, 271-300. [CrossRef]

40. Cabel, J.F.; Oelofse, M. An indicator framework for assessing agroecosystem resilience. Ecol. Soc. 2012, 17, 18. [CrossRef]

41. Kremen, C.; Miles, A. Ecosystem Services Ecology \& Society. Ecol. Soc. 2012, 17, 40.

42. Angevin, F.; Fortino, G.; Bockstaller, C.; Pelzer, E.; Messéan, A. Assessing the sustainability of crop production systems: Toward a common framework? Crop Prot. 2017, 97, 18-27. [CrossRef]

43. Meuwissen, M.P.M.; Feindt, P.H.; Spiegel, A.; Termeer, C.J.A.M.; Mathijs, E.; de Mey, Y.; Finger, R.; Balmann, A.; Wauters, E.; Urquhart, J.; et al. A framework to assess the resilience of farming systems. Agric. Syst. 2019, 176, 102656. [CrossRef]

44. Cumming, G.S.; Allen, C.R.; Ban, N.C.; Biggs, D.; Biggs, H.C.; Cumming, D.H.M.; Vos, D. DigitalCommons@University of Nebraska-Lincoln. Understanding Protected Area Resilience: A Multi-Scale, Social-Ecological Approach. 2015. Available online: http:/ / digitalcommons.unl.edu/ncfwrustaff / 179 (accessed on 15 October 2021).

45. Raza, A.; Razzaq, A.; Mehmood, S.S.; Zou, X.; Zhang, X.; Lv, Y.; Xu, J. Impact of climate change on crops adaptation and strategies to tackle its outcome: A review. Plants 2019, 8,34. [CrossRef]

46. Frank, S.; Fürst, C.; Witt, A.; Koschke, L.; Makeschin, F. Making use of the ecosystem services concept in regional planningtradeoffs from reducing water erosion. Landsc. Ecol. 2014, 29, 1377-1391. [CrossRef]

47. Ellis, F. Rural Livelihood Diversity in Developing Countries: Evidence and policy implications. Overseas Development Institute (ODI). Nat. Resour. Perspect. 2000, 40, 1-10. Available online: https://cdn.odi.org/media/documents/2881.pdf (accessed on 9 May 2021).

48. Kristjanson, P.; Bryan, E.; Bernier, Q.; Twyman, J.; Meinzen-Dick, R.; Kieran, C.; Ringler, C.; Jost, C.; Doss, C. Addressing gender in agricultural research for development in the face of a changing climate: Where are we and where should we be going? Int. J. Agric. Sustain. 2017, 15, 482-500. [CrossRef]

49. Armitage, D.; Béné, C.; Charles, A.T.; Johnson, D.; Allison, E.H. The interplay of well-being and resilience in applying a socialecological perspective. Ecol. Soc. 2012, 17, 15. [CrossRef]

50. Beauchamp, E.; Sainsbury, N.C.; Greene, S.; Chaigneau, T. Aligning resilience and wellbeing outcomes for locally-led adaptation in Tanzania. Sustainability 2021, 13, 8976. [CrossRef]

51. Ley 1876 de 2017. "Por medio de la cual se crea el Sistema Nacional de Innovación Agropecuaria y se Dictan tras Disposiciones". Congreso de Colombia. Diario Oficial. No. 50.461. Available online: http:/ /www.suin-juriscol.gov.co/viewDocument.asp?ruta= Leyes/30034416 (accessed on 20 September 2021). 
52. Kahane, R.; Hodgkin, T.; Jaenicke, H.; Hoogendoorn, C.; Hermann, M.; Dyno Keatinge, J.D.H.; D'Arros Hughes, J.; Padulosi, S.; Looney, N. Agrobiodiversity for food security, health, and income. Agron. Sustain. Dev. 2013, 33, 671-693. [CrossRef]

53. Bhattarai, B.; Beilin, R.; Ford, R. Gender, Agrobiodiversity, and Climate Change: A Study of Adaptation Practices in the Nepal Himalayas. World Dev. 2015, 70, 122-132. [CrossRef] 